УДК 785 (430) “19”

\author{
Horbal Vadim, \\ Hetman Sahaidachny National Army Academy, \\ the Department of Music Art, PhD in Arts, docent \\ orcid.org/0000-0002-0631-2617 \\ vadikdj86@ gmail.com
}

\title{
COMPOSITION OF ORCHESTRA AND PRINCIPLES OF ORCHESTRAL WRITING IN CONCERTO GROSSO G-DUR № 2 BY JOHANN GEORG PISENDEL
}

The purpose of a work. The article examines the principles of orchestral writing in the instrumental works of J. G. Pisendel (1687-1755) in the context of the genre evolution of German orchestral music of the first half and middle of the eighteenth century. Material for analysis - Concerto Grosso number 2 G-dur. The methodology is an integrated approach and is based on the use of analytical and comparative methods. Scientific novelty. During the first half and middle of the eighteenth century German instrumental music sees an intense solo performance development and the role of individual musician's skills is rising. Development of new genres, which can demonstrate performing skills, continues. One of them was a genre of instrumental concert, in which a triad "concerto grosso - instrumental solo concert - concert symphony" clearly reflected phased transition from Baroque to early classical style. The analyzed work by J. G. Pisendel as all the legacy of the artist as a whole, represents the initial phase of the process. The conclusions. Concerto grosso G-dur № 2 is written in typical concert form, with multiple alternation of ritornellos performed by all chapel instruments and musical constructions performed by a separate group of instrumentalists - so called trio. The composer tries to follow tradition and carefully constructs a typical composition of multiple bright ritornello in different keys and episodes of solo-ensemble type, which contrast in texture the full-toned tutti parts. Composition of the orchestra: 2 violins, a viola, bass (cello and harpsichord), 2 flutes, 2 oboes, bassoon, two horns. The trio is composed of two flutes, two oboes and bassoon as soloists as well as instruments of basso continuo group. Flutes and oboes solo in turns, but are often combined in a joint sound, as a result the trio becomes a quintet featuring masterfully interpreted woodwind instruments. The main function of tutti is to present the main theme, while the ensembles' role is reduced to saturation the texture with virtuoso element. trio.

Keywords: Johann Georg Pisendel, German baroque orchestra, genre Concerto grosso, principles of orchestral writing, tutti,

Горбаль Вадим Ярославович, кандидат мистецтвознавства, в.о.доцента кафредри музичного мистецтва Національної Академії Сухопутних військ імені гетьмана Петра Сагайдачного

Про склад оркестру і принципи оркестрового письма в Concerto grosso G-dur № 2 Й. Г. Пізенделя

Мета роботи. У статті вивчаються принципи оркестрового письма в інструментальних творах Й. Г. Пізенделя $(1687-1755)$ у контексті жанрової еволюції німецької оркестрової музики першої половини і середини XVIII століття. Матеріал для аналізу - Соnсеrto grosso № 2 G-dur. Методологія дослідження полягає в комплексному підході до вивчення вказаних явищ і ґрунтується на застосуванні аналітичного та компаративного методів. Наукова новизна. Протягом першої половини і середини XVIII століття в німецькій інструментальній музиці відбувається інтенсивний розвиток сольного виконавства і зростає роль індивідуальної майстерності музикантів, триває фрормування нових жанрів, у яких можна показати виконавські можливості. Одним з них став жанр інструментального концерту, у якому через тріаду «concerto grosso - сольний інструментальний концерт - концертна симфонія» чітко відобразилася поетапність переходу від барокового до ранньокласицичного стилю. Аналізований твір Й. Г. Пізенделя, як і вся спадщина митця у цілому, уособлює початковий етап цих процесів. Висновки. Concerto grosso G-dur № 2 написаний у типовій концертній формі, з багаторазовим чергуванням ритурнелю, який виконується усіма інструментами капели, та музичних побудов, що виконуються окремою групою інструменталістів - т. зв. тріо. Композитор намагається слідувати традиції і старанно вибудовує типову композицію, з багаторазовим проведенням блискучого ритурнелю в різних тональностях та епізодами сольно-ансамблевого типу, які фрактурно контрастують повнозвучному туттійному викладу. Склад голосів у tutti: 2 скрипки, альт, бас (віолончель і клавесин), 2 флейти, 2 гобої, фагот, 2 валторни. У тріо беруть участь дві фрлейти, два гобої і фрагот як солісти, а також інструменти групи basso continuo. Флейти і гобої солюють почергово, однак доволі часто об'єднуються у сумісному звучанні, внаслідок чого тріо перетворюється на квінтет за участю віртуозно трактованих дерев'яних духових інструментів. Головною функцією tutti є виклад основної теми, тоді як роль ансамблів зводиться до насичення фрактури віртуозним елементом.

Ключові слова: Йоган Георг Пізендель, німецький бароковий оркестр, жанр Concerto grosso, принципи оркестрового письма, tutti, trio.

Горбаль Вадим Ярославович, кандидат искусствоведения, и.о.доцента кафредры музыкального искусства Национальной Академии Сухопутных войск имени гетмана Петра Сагайдачного

О составе оркестра и принципах оркестрового письма в Concerto grosso G-dur № 2 И. Г. Пизенделя

Цель работы. В статье изучаются принципы оркестрового письма в инструментальных произведениях И. Г. Пизенделя (1687 - 1755) в контексте жанровой эволюции немецкой оркестровой музыки первой половины и середины XVIII века. Материал для анализа - Concerto grosso № 2 G-dur. Методология исследования состоит в комплексном подходе к изучению указанных явлений и основывается на аналитическом и компаративном методах. Научная новизна. На протяжении первой половины и середины XVIII века в немецкой инструментальной музыке происходит интенсивное развитие сольного исполнительства и возрастает роль индивидуального мастерства музыкантов, происходит формирование новых жанров, в которых можно показать исполнительские возможности. Одним из них стал жанр инструментального концерта, в котором через триаду «concerto grosso - coльный инструментальный концерт - концертная симфония» четко отразилась поэтапность перехода от барочного к раннеклассическому стилю. Проанализированное сочинение И. Г. Пизенделя, как и все наследие композитора в целом, отображает начальный этап этих процессов. Выводы. Concerto grosso G-dur № 2 написан в типичной концертной форме, с многократным чередованием ритурнеля, который исполняется всеми инструментами оркестра, и музыкальных построений, исполняемых отдельной группой инструменталистов - т. н. трио. Композитор старается следовать традициям и мастерски выстраивает композицию, в которой многократные проведения блестящего ритурнеля в разных тональностях чередуются с эпизодами сольно-ансамблевого типа, фактурно контрастируюшими полнозвучному туттийному изложению. Состав голосов в tutti: 2 скрипки, альт, бас (виолончель и клавесин), 2 флейты, 2 гобоя, фрагот, 2 валторны. В трио участвуют две флейты, два гобоя и фагот как солисты, а также инструменты группы basso continuo. Флейты и гобои солируют поочередно, однако довольно часто объединяются в совместном звучании, в результате чего трио преобразуется в квинтет с участием виртуозно трактованных деревянных духовых инструментов. Главной функциею tutti является изложение основной темы, в то время как роль ансамблевых эпизодов сводится к насыщению фактуры виртуозным элементом.

Ключевые слова: Иоган Георг Пизендель, немецкий барочный оркестр, жанр Concerto grosso, принципы оркестрового письма, tutti, trio.

(C) Horbal V., 2019 
Formulation of the problem. Recently the interest of the musicians in early music, especially the Baroque one, has increased greatly. One of the trends in this direction is to perform works of famous authors in an authentic manner, using specially made instruments. Another trend is the revival of the oeuvre of now forgotten composers who were once brilliant virtuoso musicians and had a European fame. This primarily relates to the work of German musicians who are in the shadows of the great Johann Sebastian Bach. With good reason these include an outstanding German violinist, a student of Giuseppe Torelli and Antonio Vivaldi, concertmaster of the famous Dresden Court Orchestra Johann Georg Pisendel (1687-1755). Like most musicians of the time, he combined performing with composing (approximately in 1718 he studied composition with Johann David Heinichen) and wrote mainly for his instrument or court orchestra. We know that he is the author of 12 violin concertos, a concerto for two oboes and bassoon, 4 Concerti grossi, a baroque Sinfonia, several violin sonatas with basso continuo and a sonata for solo violin [5].

Analysis of recent research. The manuscripts of works by J. G. Pisendel are kept in the Saxon State Library in Dresden (Sächsische Landesbibliothek - Staats und Universstätsbibliothek Dresden). An acquaintance with them shows that the musician was interested not in the quantity but the quality of music, and actually the study of the works for orchestra allows investigating the genre specificity of Dresden Court Orchestra repertoire at the time of the Elector Augustus II the Strong (from 1717 to 1733).

Based on the above, the purpose of this article is to define the principles of orchestral writing in the instrumental works of J.G. Pisendel written for the Dresden Court Orchestra, in the context of genre evolution of the of German orchestral music of the first half and middle of the eighteenth century. The material for analysis is Concerto grosso № 2 G-dur.

As we know, during the first half and middle of the eighteenth century the orchestral genres of German instrumental music, as European music in general, experienced the transition from Baroque to early classicism, with the adoption of new stylistic qualities of musical language selected because of evolutionary changes with some influence of foreign trends of musical genres development in the Italian and French music.

In the genre system of instrumental music in connection with the intensive development of solo performance and the increasing role of individual skills of musicians-instrumentalists, the process of formation of new genres, in which musicians could clearly demonstrate their performing capabilities, is ongoing. One of them was a concert genre, the other - the genre of symphony; both existed in multiple versions, reflecting the phased transition from Baroque to early classical style and were well represented in the repertoire of German instrumental chapels of the first half and middle of the eighteenth century.

The genre of instrumental concert is characterized by solo parties, musical material of which is contrasted to the sound of the whole orchestra. In the genre of concerto grosso of the first half of the eighteenth century it was an ensemble composed of three instrumentalists which was involved in creating such contrast [2]; different in musical density texture tutti and trio created timbre-dynamic contrasts inherent to the aesthetics of Western European Baroque music. The emergence of the concerto grosso is associated with the Italian musical culture, including the work of Arcangelo Corelli. Since the beginning of the eighteenth century, this genre spread to the German lands, gained great popularity in the court music, contributed to the development of collective and individual performance. Composers wrote pieces for instrumental composition of the orchestras and counted on musicians' performing skills. The analysis of instrumental scores of concerto grosso by J. D. Heinichen, J.G. Pisendel, Jan Dismas Zelenka, Jean-Baptiste Volumier, Georg Benda and other musicians of Saxon Court, written specifically for the Dresden Court Orchestra, clearly illustrate this [4].

The formation of another principle of construction of a concert, with an emphasis on one or two solo instruments from a trio (such as operatic aria or duet) initiated the emergence and development of the genre of a solo instrumental concert, which demonstrated noticeable tendency to form signs of the early classical style. No coincidence that this genre took a leading position in the genre system of classicism, and in the works of its outstanding representatives (Wolfgang Amadeus Mozart, Ludwig van Beethoven) it won the classic signs of perfection. A characteristic feature of a solo instrumental concert was the differentiation of the whole mass of orchestral voices into relief and background, with a higher level of virtuosity of the soloists than other instruments parts and soloists play accompanied by the orchestra (in concerto grosso the orchestral tutti and ensemble of soloists alternated). This genre became extremely popular in the orchestral culture in Dresden and Berlin, where the outstanding virtuosos performed - Pierre Gabriel Bufarden, Johann Joachim Quantz, J. G. Pisendel, J. B. Volumier, Philip Emanuel Bach and others.

Innovations in orchestral compositions in Mannheim orchestra gave rise to the emergence of the genre of a concert symphony with soloists' parts and concert orchestral voices, i.e. the concert principle applied not only to soloists, but also to the orchestra, which allowed each member of the orchestra to demonstrate skills of a soloist. Extremely popular in the early classical period, the concert symphony genre went out of use in the future, replaced by the classical symphony, and is virtually unexplored as of today.

The style evolution of the concert principle clearly manifests in form making, as repeatedly mentioned in the works of scientists. Our analysis of orchestral scores proves that the effect of evolutionary principle is evident in instrumentation parts and in the ratio of orchestral voices with equal brilliance, indicating the organic interaction of formative and orchestral-performing factors on the way of evolutionary change. Works 
by J. G. Pisendel represent the initial stage of this process and take the first step on the path of rapid evolutionary transformation.

Concerto grosso G-dur № $2^{1}$ (J.II.2) by J. G. Pisendel is a work for orchestra, which has features typical of the Baroque concerto grosso. It is written in so called alternative concert form extremely popular in form making of Western Baroque instrumental music. This form is characterized by multiple alternations of ritornello, performed by all the orchestra instruments (the first one is like overture to an operatic aria), and musical constructions performed by a separate group of instrumentalists - so called trio. The composer tries to follow tradition and carefully builds a typical composition with multiple brilliant ritornellos in different keys and episodes of solo-ensemble type, whose texture contrasts sonorous tutti presentation. However, orchestral parts are quite specific for interpretation, including the distribution of musical material in tutti and ensembles (which actually are no longer trios), which to some extent takes the work beyond the genre of concerto grosso.

Orchestra composition: 2 violins, a viola, bass (cello and harpsichord), 2 flutes, 2 oboes, bassoon, 2 French horns; the trio includes two flutes, two oboes and bassoon as soloists and accompaniment instruments (mainly of basso continuo group). Flutes and oboes solo in turns, but quite often are combined in a joint sound, as a result the trio actually becomes a quintet featuring masterfully interpreted woodwind instruments.

The main function of tutti is to present the main theme, while the role of ensembles is reduced to saturation the texture with virtuoso element. As far as performance is concerned, this requires coordinated play of the whole orchestra to perform ritornellos (adherence to the same tempo, articulation, same phrasing, accentuation, etc.) that demonstrates the skills of collective performance, and solo-ensemble constructs that make separate forms and are organically embedded in tutti, which demonstrate technical excellence of individual performance of virtuoso soloists, the ability to feel a partner and create an ensemble.

Flutes and oboes - are the only orchestral instruments which do not participate in the initial ritornello. This confirms their solo status and at the same time overcomes the baroque performing tradition, according to which the soloists participated in tutti parts together with musicians-ripienists. In other melodic instruments parts this theme is written in the bass keys, similar to parts for instruments of basso continuo group. This means that it is played in unison, and artists play in the tessitura within the range of their instruments. Thus, the parties of first violins in the first six bars of note text entry are done in the bass keys and only the seventh bar starts with violin clef.

Ritornello consists of two constructions, similar in structure to two half-phrases of a music period (second half-phrase is repeated twice with some varied changes), repeating the theme in dominant key (in the first half-phrase $G$-dur, in the second $-D$-dur). Along with individually built tone, both sentences have also different orchestration.

The first ritornello is written in unison with majority of the orchestra instruments (except flutes and oboe), so it sounds strongly and powerfully. In the second Half-phrases the unison mode is replaced by detailed textural weaving. The theme is supported by bass instruments (cello, bassoon, harpsichord) and is in the lowest orchestral voice.

Other parts, including the flutes and oboes acceding to the overall sound, form an elegant, multicomponent accompaniment with:

- triple imitation of a new lyrical theme that will continue to evolve along with the ritornello theme (imitation voices: I - first violins + the first and second flutes + first oboe; II - second violins + second oboe; III - violas + the first and second horns);

- short and lively melodic counterpoints in flutes and oboes parts with double thirds;

- harmonious figuration with elements of hidden double-voicedness in first and second violins parts.

Later (from bar 11), bass voice switches to its typical figures of motion - repetitions of the same sound in small rhythmic durations that create a harmonious foundation for the whole polyphonic sound structure. High melodic voices start moving like sounds of dissonant chords, full-scale triads and their inverse cadence is approaching.

In the second half-phrase of the material the main theme moves into high voice and is entrusted to instruments of melodious specialization (the first violin, the first and second flutes in unison), oboes and French horns perform melodic counterpoints, the second violins and violas - harmonic figuration.

In general, in the tutti a four-voice texture of homophonic-harmonic type is formed, based on two melodic voices, harmonic filling and melodized bass line. The distribution of voices between the instruments constantly varies. Thus, in the second half-phrase of ritornello the following distribution is observed:

- first melodic voice - first violins, first and second flutes, first oboes;

- second melodic voice - second violins and second oboes;

- harmonious filling - violas and French horns;

- bass voice - cello, bassoon, harpsichord.

In addition, in the same block we have one more combination of instruments:

- the first and second violins are entrusted with harmonious chord configuration; 
- violas and French horns develop the melodious nucleus of the new theme;

- instruments of basso continuo group perform the ritornello theme.

Similar transformations continue in the next parts. Thus, the functions of all instruments in tutti are wider than traditional ones, rooted in the practice of contemporary orchestral performance, which highlights versatility of each instrument.

Despite the advantage of homophonic-harmonic composition ritornello is related to polyphonic form making, especially at the thematic level. Like fugal forms of instrumental music of the Baroque epoch, the ritornello theme is based on several intonation elements - the core and its development, the sequential development of motives that form the core of the theme, varied melodic counterpoints, including those which acquire the status of independent thematic formation, etc. The unfolded in time ritornello is characterized by fluidity, absence of square structural constructions, sudden cadence. The above-mentioned features are emphasized by orchestral means, in particular - principles of instruments selection.

In parts for one voice the performed material is almost the same, excluding special articulation in figurations, taking into account the specific features of orchestra instruments. For example, the violins do the figuration performance on three strings, based on an open string «D» on strong beat, so the effect of hidden two-voicedness is formed; violas, cellos and bassoons specialize in repeating one sound in an even rhythm, and horns - the repetition of sound in a fanfare rhythm. At the same time, unison presentation of ritornello theme in the first half-phrase and performance of the same melodic constructions by such different instruments as, say, viola, oboe and horn, is evidence that the musicians of the Dresden Orchestra tried to follow common principles of sound studies in creation and performance of musical phrases, etc., despite the specificity of the process of sound formation by a musical instrument.

The instruments of related orchestral voices (e.g. first and second violins, first and second flutes, first and second horns etc.) are quite often combined together like a third duplicating which diversifies the fourvoicedness with many varied combinations. This happens in tutti during ritornello.

Features of the trio construction are somewhat different. They depend not only on the number of instruments involved in solo-ensemble music-making, but, above all, are determined by the quality of the material. Solo-ensemble constructs inherently possess virtuoso quality and this is where the concert principles are developed, including the principle of competition. In the analyzed work the ensemble of soloists compete with each other.

Trio in concerto grosso by Pisendel has three compositions:

1) two oboes and solo bassoon;

2) two solo flutes accompanied by the first and second violins (in unison) that perform the accompaniment;

3) two solo flutes, two solo oboes, solo bassoon, first and second violins (unison).

The material performed by the soloists resembles fioritures in opera arias and is performed alternately by the first and second composition on the basis of imitation at a distance (so called imitation without counter theme) that forms the echo effect. During the combination of the two compositions in united sound this competition is transferred to another plane and continues not from afar but very close, and the transfer of two-voiced passages from one pair of soloists to another forms another imitation structure - a circle canon. Imitations also play an important role in soloists' duets, when the first performer plays alone, and the other picks up the same theme in the next measure. In such cases, the notation indicated solo, unlike soli when two instruments are performing, mainly during the third duplication.

Solo parts treated in the concert manner demand from the artists the sound equality of all registers, excellence on the upper notes, proper distribution of breathing, phrasing, accents and more. They were created for well-trained oboist and flutists, and such artists composed the Dresden Royal Orchestra. Pisendel was an excellent violinist, but in his score he gives his instrument not a solo function, but an accompanying one. A total of 12 parts are indicated in the score, and if each one of them was performed by one musician, the orchestra would consist of 12 musicians. However, in this case the balance between the voices of the orchestra would be broken. Besides, the manuscript has three lists of parts for first and second violins, two lists - parts for viola, cello and bassoon, one list - parts for first and second flutes, first and second oboes, first and second horns and a harpsichord. Given that one part was played by two musicians (except the harpsichord part), the number of artists increased significantly compared to the score voices.

The conclusions. Concerto grosso by J. G. Pisendel and other Dresden Court musicians certainly were landmark works both in the development of the genre, and in the improvement of the collective principles of orchestral playing. In the interpretation of musical instruments a focus is placed on wind instruments as soloists, while in concerto grosso by A. Corelli, Francesco Geminiani and Georg Friedrich Handel the soloists trio consisted of only a string instruments group - two violins and a cello. It wasn't a coincidence with the famous Italian virtuoso violinists as they knew well the technical capabilities and the "soul" (Charles Burney) of their instrument. G.F. Handel used this composition of soloists, to some extent, paying tribute not only to tradition, but also to the then existing musical tastes. It is known that in England during the first half of the eighteenth century, the genre remained one of the most common, as evidenced by the constant publication of collections of concerto grosso, which were later copied by hand. The main music 
publisher of Handel's music published concerto grosso by most famous Italian composers - op. 2 by Tomaso Albinoni (1709), op. 3 by A. Vivaldi (1714), op. 6 by A. Corelli (1715), op. 3 by F. Geminiani (1730), and in the 30s - concerto grosso by G.F. Handel: op. 3 (1734) and op. 6 (1739) [5].

Dresden musicians stood somewhat aside from these processes and developed their own orchestral style based on the fusion of Italian and French performing manner. They also introduced in the composition of the Orchestra the instruments that had long been common in the German musical culture, but not very widely used in orchestral playing (flute, horn, etc.). Hence this attention to mixed orchestral compositions, and the wind concertino, which appears in the German works together with the string one: instead of two violins and cello the German composers increasingly used two oboes with the bass of unison bassoons; sometimes the oboes are replaced by two flutes, and then they are joined by a bassoon or another bass (in Pisendel's works - unison of the first and second violins in lower case). Another important innovation is strengthening a virtuoso component in the treatment of soloists' parts for wind instruments in solo-ensemble constructs, emphasizing the contrast between solo and tutti parts and ultimately distinguishing between solo and orchestral voices.

Thus, the Italian the roots of concerto grosso didn't prevent J. G. Pisendel and other German musicians from breathing new independent life into it. The transformations covered not only the orchestra, which permanently embraced oboes and on parity basis included wooden and brass wind instruments (flutes, bassoons, horns), but the interpretation of the soloists instruments parts, especially the wind ones - compared to earlier times, they were filled with incredible virtuoso brilliance.

The study of the creative legacy of $\mathrm{J}$. G. Pisendel showed that this musician deserves much more attention from artists and researchers than he has had hitherto, also, it is advisable to study the evolution of the German Orchestra of baroque and early classicism period through the example of his work and the work of his colleagues in the Dresden Court Orchestra, who are now considered as composers of "second-line" [3].

\section{Примітки}

${ }^{1}$ The concert number is given according to information from the Grove dictionary [5], which coincides with the symbol on the front page of music manuscript. Also known cataloging H. R. Jung, which is currently indicated concert titled Concerto in G major, J.II.2. Source of note text: Sächsische Landesbibliothek - Staats und Universstätsbibliothek Dresden (SLUB) http://hz.ims/p. info/files/imglnks/usimg/e/e3/IMSLP324338-PMLP525067-320472272.pdf [6].

\section{תimepamypa}

1. Горбаль В. Оркестровая культура Саксонии первой половины XVIII века // GESJ: Musicology and Cultural Science. Тбилиси : Тбилисская государственная консерватория имени Вано Сараджишвили, 2013. № 1 (9). C. 84-91. URL : http://gesj.internet-academy.org.ge/ru/list_artic_ru.php?b_sec=muz\&issue=2013-12

2. Зейфрас H. Concerto grosso в музыке барокко / Проблемы музыкальной науки. М. : Сов. композитор, 1975. Вып. 3. C. $379-406$.

3. Композиторы «второго ряда» в историко-культурном процессе. Сборник статей / ред.-сост. А. М. Цукер; Ростовская государственная консерватория (академия) имени С. В. Рахманинова. М. : Композитор, 2010. 328 с.

4. Landmann O. The Dresden Hofkapelle during the Lifetime of Johann Sebastian Bach / Early Music. 1989. Vol. 17. № 1, Feb. P. 17-30.

5. The New Grove Dictionary of Music and Musicians (A - Z). In 29 vol. London, 2000. (CD-ROM).

6. Pisendel Johann Georg. Concerto grosso G-dur № 2 / Sächsische Landesbibliothek. Staats und Universstäts bibliothek Dresden. URL : http://hz.imsIp.info/files/imglnks/usimg/e/e3/IMSLP324338-PMLP525067-320472272.pdf

\section{References}

1. Horbal, V. (2013). Orchestral culture Saxony first half XVIII century. Musicology and Cultural Science. Electronic Scientific Journal, 1. URL : http://gesj.internet-academy.org.ge/ru/list_artic_ru.php?b_sec=muz\&issue=2013-12. [in Russian]. Russian].

2.Zejfas, N. (1975). Concerto grosso in baroque music. Problems of musical science, 3. Moscow: Sovet. Kompozitor. [in Russian].

3.Composers of the "second row" in the historical and cultural process (2010). Anatoly Tsuker (ed.). Moscow: Kompozitor. [in English].

4.Landmann, O. (1989). The Dresden Hofkapelle during the Lifetime of Johann Sebastian Bach. Early Music, 17, 1, Feb. [in

5.The New Grove Dictionary of Music and Musicians (A - Z) (2000). In 29 vol. London, (CD-ROM). [in English].

6.Pisendel, J. G. Concerto grosso G-dur № 2 / Sächsische Landesbibliothek. Staats und Universstäts bibliothek Dresden. URL : http://hz.imslp.info/files/imglnks/usimg/e/e3/IMSLP324338-PMLP525067-320472272.pdf 